\title{
Adolescence, pregnancy and domestic violence: social conditions and life projects
}

\author{
Adolescência, gravidez e violência doméstica: condições sociais e projetos de vida \\ Adolescencia, embarazo y violencia doméstica: condiciones sociales y proyectos de vida
}

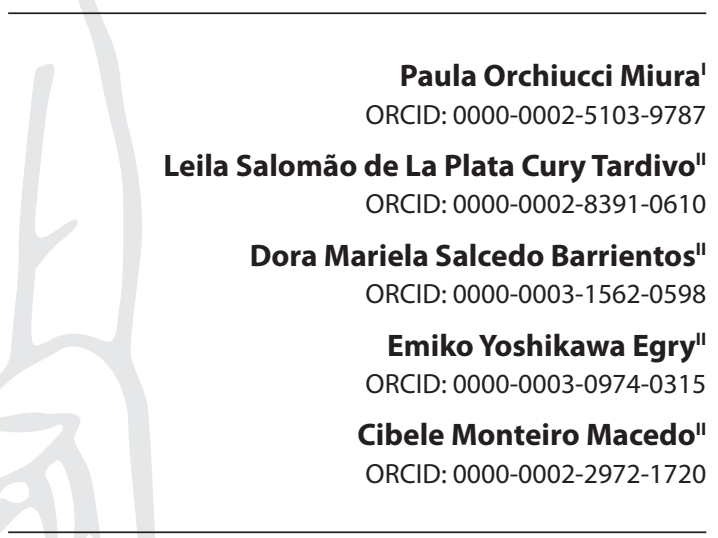

'Universidade Federal de Alagoas. Alagoas, Maceió, Brazil. "Universidade de São Paulo. São Paulo, São Paulo, Brazil.

How to cite this article:

Miura PO, Tardivo LSLPC, Barrientos DMS, Egry EY, Macedo CM. Adolescence, pregnancy and domestic violence: social conditions and life projects.

Rev Bras Enferm. 2020;73(Suppl 1):e20190111. doi: http://dx.doi.org/10.1590/0034-7167-2019-0111

Corresponding author:

Paula Orchiucci Miura

E-mail: paula.miura@ip.ufal.br

EDITOR IN CHIEF: Antonio José de Almeida Filho ASSOCIATE EDITOR: Hugo Fernandes

Submission: 07-11-2019 Approval: 11-06-2019

\begin{abstract}
Objective: to analyze the social conditions and life projects of non-pregnant adolescents, pregnant adolescents and pregnant women who are victims of domestic violence. Methods: This is a exploratory, descriptive and comparative study of a quantitative and qualitative character. Ninety adolescents between 12 and 18 years old participated in the study, consisting of three groups: Group A (30 non-pregnant adolescents with no history of violence); Group B (30 pregnant adolescents with no history of violence); and Group C (30 pregnant adolescents with a history of violence). The tools used were a questionnaire of characterization of socioeconomic conditions, Inventory of Domestic Violence Against Children and Adolescent Phrases and structured interview. Results: Group C adolescents had lower schooling, higher school dropout, lower family income and short-term life projects. Final considerations: in life projects and social conditions (marital status, education, living conditions and family income) there was some difference between the groups.

Descriptors: Adolescence; Pregnancy; Domestic Violence; Social Conditions; Life Projects.
\end{abstract}

\section{RESUMO}

Objetivo: analisar as condições sociais e os projetos de vida de adolescentes não gestantes, adolescentes gestantes e gestantes vítimas de violência doméstica. Métodos: trata-se de um estudo exploratório, descritivo e comparativo, de natureza quanti-qualitativa. Participaram do estudo 90 adolescentes entre 12 e 18 anos, constituindo-se em três grupos: Grupo A (30 adolescentes não grávidas e sem histórico de violência); Grupo B (30 adolescentes grávidas e sem histórico de violência); e Grupo C (30 adolescentes grávidas e com histórico de violência). Os instrumentos utilizados foram: questionário de caracterização das condições socioeconômicas, Inventário de Frases de Violência Doméstica contra Crianças e Adolescentes e entrevista estruturada. Resultados: adolescentes do Grupo $C$ apresentaram escolaridade mais baixa, maior abandono escolar, menor renda familiar e projetos de vida a curto prazo. Considerações finais: nos projetos de vida e nas condições sociais (estado civil, escolaridade, condição de moradia e renda familiar), observou-se certa diferença entre os grupos.

Descritores: Adolescência; Gravidez; Violência Doméstica; Condições Sociais; Projeto de Vida.

\section{RESUMEN}

Objetivo: analizar las condiciones sociales y los proyectos de vida de adolescentes no embarazadas, adolescentes embarazadas y mujeres embarazadas que son víctimas de violencia doméstica. Métodos: estudio exploratorio, descriptivo y comparativo de naturaleza cuantitativa y cualitativa. El estudio incluyó a 90 adolescentes entre 12 y 18 años, que consta de tres grupos: Grupo A (30 adolescentes no embarazadas sin antecedentes de violencia); Grupo B (30 adolescentes embarazadas sin antecedentes de violencia); y Grupo C (30 adolescentes embarazadas con antecedentes de violencia). Los instrumentos utilizados fueron: cuestionario de caracterización de condiciones socioeconómicas, Inventario de frases de violencia doméstica contra niños y adolescentes y entrevista estructurada. Resultados: los adolescentes del Grupo $C$ tenían menor escolaridad, mayor deserción escolar, menores ingresos familiares y proyectos de vida a corto plazo. Consideraciones finales: en los proyectos de vida y las condiciones sociales (estado civil, educación, condiciones de vida e ingresos familiares), hubo una cierta diferencia entre los grupos.

Descriptores: Adolescencia; Embarazo; Violencia Doméstica; Condiciones Sociales; Proyectos de Vida. 


\section{INTRODUCTION}

\section{Adolescence and Life Projects}

Adolescence is a unique phase in an individual's life that lies between childhood and adulthood. According to Levisky(1), at this moment in life, the identification process is in complete restructuring, and the adolescent needs family and social support for the construction of this identity. Moreover, it is a period of intense physical, psychic and affective changes.

According to Macedo et al. (2), plans for the future, both personal and professional, begin to be considered in early adolescence. According to Freud ${ }^{(3)}$, through work, the individual is and valued by society, being able to discharge his libidinal, aggressive and erotic impulses. In this way, the adolescent begins to invest libidinally in the profession. Besides being an important aspect in the construction of your identity, which is the professional identity; The work also emerges as a real possibility of the realization of their dreams, their ideals, as well as the achievement of financial independence ${ }^{(3)}$.

The pursuit of this financial independence, educational background, recognition of a social role through profession, material achievement and family constitution are more characteristic goals of late adolescence ${ }^{(2)}$. A study sought to investigate future projects of public high school students and concluded that the main objectives of students were to continue their studies and work ${ }^{(4)}$. In addition to dreams and desires for professional achievement, financial independence, at the end of this phase of life, marriage can also be a wish and a possibility ${ }^{(2)}$.

However, in situations such as low socioeconomic conditions, teenage pregnancy and domestic violence, dreams, desires and the pursuit of their ideals may be interrupted and / or compromised by the crossing of these problems. For Costa and Assis ${ }^{(5)}$, situations of vulnerability experienced by adolescents may affect the planning of their future, as risk exposure and lack of confidence in adult protection become obstacles to thinking about this planning.

\section{Teenage Pregnancy}

Teenage pregnancy is still a hotly debated and debated topic worldwide today due to its significant incidence. Worldwide, approximately 16 million 15- to 19-year-olds and 2 million under-15s become pregnant each year. Half of these deliveries occur in seven countries: Bangladesh, Brazil, the Democratic Republic of the Congo, Ethiopia, India, Nigeria, and the United States of America ${ }^{(6)}$. In 2016, in Brazil, 24,084 births of girls between 10 and 14 years old were identified, and 476,543 between 15 and 19 years old ${ }^{(7)}$.

Some surveys indicate that the largest number of teenage mothers are in the lower classes, with a lower chance of professional qualification and greater social vulnerability ${ }^{(8-11)}$. Data also show relationship between teenage pregnancy and fewer years of schooling, $18.7 \%$ of adolescents between 15 and 19 years old and with up to 7 years of schooling have 1 or more children, while those with 8 or more years of schooling this percentage drops to $8 \%{ }^{(9)}$. A research shows that dropping out of school and lack of participation in the labor market stem from both teenage motherhood and the socioeconomic status in which adolescents previously lived $^{(10-11)}$. School dropout, in another research, was identified not as a consequence of teenage pregnancy, but as a fact that occurred prior to the young woman's pregnancy ${ }^{(12)}$.

These data agree with the descriptive review by Dávila et al. (13) $^{\text {. }}$ The following psychosocial factors related to teenage pregnancy were identified as: violence experienced during adolescence; sexual abuse; low self-esteem; low income; eating disorders; alcoholism; smoking; drug addiction; early onset of sex; abusive families; lack of access to information and family planning. The study by Garwood et al. ${ }^{(14)}$ identified childhood maltreatment as a significant risk factor for teenage pregnancy among low-income youth. Accordingly, the study by Negriff et al. ${ }^{(15)}$ specifically demonstrated that adolescents who suffered neglect had a higher frequency of risky sexual behaviors and a higher rate of teenage pregnancy than girls who did not experience these situations of violence. In this direction, the work of Miura et al. ${ }^{(16)}$ addressed the potentialized vulnerability and abandonment of life projects when teenage pregnancy was also crossed by the history of intrafamilial violence and the use and abuse of licit and illicit drugs.

It is believed that the high rate of teenage pregnancy in the world, and specifically in Brazil, points to a lack of studies and policies with this public. It is important to develop work in this area, especially in the understanding of factors related to pregnancy at this stage of life and if this condition interferes with young people's life projects. Given the above, this paper sought to answer some questions: is there a difference in the social conditions of pregnant women, non-pregnant women and pregnant women victims of violence? Does teenage pregnancy interfere with teenage life projects? Does domestic violence experienced by pregnant adolescents interfere with young people's life projects?

\section{OBJECTIVE}

To analyze the social conditions and life projects of non-pregnant adolescents, pregnant adolescents and pregnant women who are victims of domestic violence.

\section{METHODS}

\section{Ethical aspects}

This study was approved by the Research Ethics Committee of the institution responsible. The participating adolescents completed and signed the Consent Term (CT), as well as their parents andor guardians, the Informed Consent (IC). All ethical precepts recommended by the Brazilian National Health Board (Conselho Nacional de Saúde), according to Resolution 466/12, were met.

\section{Type of study}

This is a quantitative and qualitative research. For Minayo and Sanches ${ }^{(17)}$, the quantitative-qualitative method complements, "the quantitative study can generate questions to be qualitatively deepened, and vice versa" (p. 247). In addition, it is an exploratory, descriptive and comparative study. It is exploratory ${ }^{(18)}$, as there is the intention of approaching and deepening the studied theme. It is descriptive ${ }^{(18)}$, as it is intended to observe, record and describe about the researched and comparative phenomenon ${ }^{(18)}$ due to the comparison made between different groups. 


\section{Study setting and Data source}

The present study was developed with 90 adolescents between 12 and 18 years old, consisting of three groups: Group A, consisting of 30 non-pregnant adolescents without evidence of history of violence; Group B, consisting of 30 pregnant adolescents with no evidence of a history of violence; Group C, consisting of 30 pregnant adolescents with evidence of a history of violence through institutional reports. Group A and B participants came from health institutions and Group C from host and/or health institutions.

\section{Collection and organization of data}

Firstly, one of the researchers contacted the heads of the host and health institutions to present the research, and to request authorization to conduct the investigation, which was promptly authorized, given the importance of conducting studies on this subject. The host institution is an equipment that welcomes children and adolescents who suffered some kind of intrafamily violence. In this place, the invitation was made collectively to all the adolescents, who voluntarily agreed to participate in this research. The health institution offers specialized services to the adolescent public, in this place, the invitation was made individually according to the presence of the adolescent. Following the invitation, interviews with the adolescents were scheduled according to their availability, and they would attend at the scheduled time and day, accompanied by the host institution's educators or their guardians.

In a quiet room, free of noise and interference, the meetings were held with the adolescents individually, which lasted about 45 minutes each. The tools used in the three groups were a questionnaire to characterize socioeconomic conditions (age, race/color, education, work, living conditions and family income); Inventory of Domestic Violence Against Children and Adolescent Phrases (IFVD - Inventário de Frases de Violência Doméstica contra Crianças e Adolescentes) ${ }^{(19)}$; and structured interview on the theme: life project of adolescents.

IFVD application was performed in order to contribute to the identification of potential adolescents who are victims of domestic violence. IFVD consists of 57 easy-to-understand sentences (which do not address violence directly) that suggest some kind of victimization experience. The phrases are related to the experience of domestic violence, and thus related to cognitive, behavioral, emotional, physical and sexual disorders. The maximum inventory score is 47 , and the total sum of points equal to or greater than 22 indicates that the respondent may be a victim of domestic violence. Tardivo and Pinto Junior ${ }^{(19)}$ point out that it cannot be safely stated that the child suffers some kind of violence without any other diagnosis, thus the IFVD is an auxiliary and useful tool applied fundamentally in children and adolescents between 6 and 18 years. However, when there is suspicion, this data is quite indicative.

The interviews were recorded and later transcribed for data analysis. The researchers who conducted the interviews were familiar with the norms and routine of the institutions, as well as affinity in working with adolescents, thus facilitating access to the adolescents participating in the research.

Groups A and B were composed of adolescents from a health institution and without a history of violence, i.e., it was not identified in the reports of young women experience of domestic violence and the average IFVD score ${ }^{(19)}$ was below 22 points (Group A (mean=12.60) and Group B (mean=14.47)). Group C was composed of adolescents with a history of violence from a health institution or a host institution (legally children and adolescents living in this institution have experienced any kind of domestic violence at some point in their lives). In this Group $\mathrm{C}$, the reports of young women experiencing domestic violence were identified and the average IFVD score was 22 points or higher (mean=28.63).

\section{Data analysis}

For the analysis we considered three groups described above (Group A, B and C). Data from the three groups were analyzed comparatively. Data on socioeconomic conditions were statistically analyzed using the chi-square test (x2), with a significance level of $5 \%$ ( $p$ value $<0.05$ ). The interviews were analyzed based on the content analysis method ${ }^{(20)}$, as well as tabulated and statistically analyzed by the test described above.

Chi-square test (x2) was performed between Group A and B; Group B and C; Group A and C, as well as between the three Groups $A, B$ and $C$. When a significant difference was observed in the three pairs of groups ( $A-B, B-C$, and $A-C)$, the test was performed comparing the data of the three groups, keeping the $p$ value of this test only, but when not, the $p$ value of the group pairs tested was maintained to make explicit which of the group pairs was statistically significant or not. Peer-to-peer analysis was performed to identify significant differences or not between all groups and in all items analyzed.

\section{RESULTS}

\section{Socioeconomic profile}

The following table presents the data regarding the socioeconomic profile of the interviewed adolescents.

Regarding age and race/color, the statistical analysis between the three groups showed no significant difference, $p$ value respectively $p<0.2769$ and $p<0.503037$. Regarding marital status, a significant difference was observed between the three groups ( $p$ $<0.001446$ ), but when pairwise statistical analysis was performed, it was noticed that there was no significant difference between B-C $(p<0.349018)$.

Regarding education, a significant difference could be observed between the three groups ( $p<0.0149$ ), with Group A presenting a lower percentage of young people in Elementary II compared to the other groups. Statistical analysis of the age-grade lag between the three groups showed a significant difference with $p$ $<0.00001$. The statistical analysis of whether or not the teenager was studying was significant between the three groups, but in the pairwise analysis, there was no significant difference between Group B-C ( $p<0.052053)$. Regarding housing and family income, there was a significant difference between the three groups (housing - $p<0.004075$ and family income $-p<0.000369$ ), but when pairwise statistical analysis was performed, it was found that there was no significant difference between $A B$ (housing $p$ $<0.202595$, family income $-\mathrm{p}<0.131286$ ). 
Table 1- Socioeconomic profile of the interviewed adolescents ( $n(\%))$ and $p$ value

\begin{tabular}{|c|c|c|c|c|}
\hline & $\underset{n=30}{\operatorname{Group} A}$ & $\underset{n=30}{\operatorname{Group} B}$ & $\underset{n=30}{\operatorname{Group} C}$ & $p$ value \\
\hline Age (mean) & 15.9 years & 17 years & 16.6 years & $p<0.2769$ \\
\hline $\begin{array}{l}\text { Race/Color } \\
\text { White } \\
\text { Mixed-race } \\
\text { Black } \\
\text { Others }\end{array}$ & $\begin{array}{l}(13) 44 \% \\
(9) 30 \% \\
(7) 23 \% \\
(1) 3 \%\end{array}$ & $\begin{array}{c}(11) 37 \% \\
(15) 50 \% \\
(3) 10 \% \\
(1) 3 \%\end{array}$ & $\begin{array}{c}(12) 40 \% \\
(10) 33 \% \\
(8) 27 \% \\
---\end{array}$ & $p<0.503037$ \\
\hline $\begin{array}{l}\text { Marital Status } \\
\text { Single } \\
\text { Married/living with partner } \\
\text { Fiancee }\end{array}$ & $\begin{array}{c}\text { (30) } 100 \% \\
--- \\
---\end{array}$ & $\begin{array}{c}(18) 60 \% \\
(10) 33 \% \\
(2) 7 \%\end{array}$ & $\begin{array}{c}(20) 67 \% \\
(10) 33 \% \\
---\end{array}$ & $\begin{array}{c}p<0.001446 \text { (A-B-C test) } \\
p<0.000553 \text { (A-B test) } \\
p<0.002479 \text { (A-C test) } \\
p<0.349018 \text { (B-C test) }\end{array}$ \\
\hline $\begin{array}{l}\text { Education } \\
\text { Studying }\end{array}$ & (30)100\% & (13)43.3\% & (6)20\% & $\begin{array}{c}p<0.001446 \text { (A-B-C test) } \\
p<0.00001 \quad(\mathrm{~A}-\mathrm{B} \text { test) } \\
p<0.00001 \quad(\mathrm{~A}-\mathrm{C} \text { test }) \\
p<0.052053 \text { (B-C test) }\end{array}$ \\
\hline $\begin{array}{l}\text { Elementary School II } \\
\text { Incomplete High School } \\
\text { Complete High School } \\
\text { Higher Education } \\
\text { Age-grade lag }\end{array}$ & $\begin{array}{l}(6) 20 \% \\
(13) 43.3 \% \\
(6) 20 \% \\
(5) 16.7 \% \\
(4) 13.3 \%\end{array}$ & $\begin{array}{c}43.3 \% \\
20 \% \\
26.7 \% \\
10 \% \\
(19) 63.3 \%\end{array}$ & $\begin{array}{c}56.7 \% \\
36.7 \% \% \\
6.7 \% \\
--- \\
(28) 93.3 \%\end{array}$ & $\begin{array}{l}p<0.0149 \\
p<0.00001\end{array}$ \\
\hline $\begin{array}{l}\text { Living Conditions } \\
\text { Host institution } \\
\text { Own } \\
\text { Leased } \\
\text { Others } \\
\text { Access to light, water, sewage, and garbage collection }\end{array}$ & $\begin{array}{l}(23) 76.7 \% \\
(5) 16.7 \% \\
(2) 6.6 \% \\
(30) 100 \%\end{array}$ & $\begin{array}{c}(18) 60 \% \\
(11) 36.7 \% \\
(1) 3.3 \% \\
(30) 100 \%\end{array}$ & $\begin{array}{c}(7) 23.3 \% \\
(14) 46.7 \% \\
(7) 23.3 \% \\
(2) 6.7 \% \\
(30) 100 \%\end{array}$ & $\begin{array}{c}p<0.004075 \\
p<0.004075 \text { (A-B test-C) } \\
p<0.202595 \text { (A-B test) } \\
p<0.023093 \text { (A-C test) } \\
p<0.033221 \text { (B-C test) }\end{array}$ \\
\hline $\begin{array}{l}\text { Family Income* } \\
\text { Over } 4 \mathrm{mw} \\
2 \text { to } 4 \mathrm{mw} \\
1-2 \mathrm{mw} \\
\text { They could not answer } \\
\text { No income (residing in an institution and not working) }\end{array}$ & $\begin{array}{l}(10) 33.3 \% \\
(6) 20 \% \\
(3) 10 \% \\
(11) 36.7 \% \\
---\end{array}$ & $\begin{array}{c}(5) 16.7 \% \\
(11) 36.7 \% \\
(7) 23.3 \% \\
(7) 23.3 \% \\
---\end{array}$ & $\begin{array}{c}--- \\
(9) 30 \% \\
(7) 23.3 \% \\
(7) 23.3 \% \\
(7) 23.3 \%\end{array}$ & $\begin{array}{c}p<0.000369 \text { (A-B test-C) } \\
p<0.131286 \quad(\mathrm{~A}-\mathrm{B} \text { test) } \\
p<0.00048 \quad(\mathrm{~A}-\mathrm{C} \text { test) } \\
p<0.015924 \text { (B-C test) }\end{array}$ \\
\hline
\end{tabular}

Note: * Considering minimum wage of 788.00 reais (Brazil's currency. About 180 US Dollars) ${ }^{(21)}$.

\section{Life Projects}

Life project was the theme addressed in the interviews with the adolescents, each of them reported more than one plan, wish or dream, which were tabulated and accounted for according to Table 2 .

Table 2 - Life projects reported by participating adolescents n (\%)

\begin{tabular}{lccc}
\hline Life Projects & Group A & Group B & Group C \\
\hline Going to college & $(22) 73.3 \%$ & $(15) 50 \%$ & $(4) 13.3 \%$ \\
Working & $(12) 40 \%$ & $(17) 56.7 \%$ & $(16) 53.3 \%$ \\
Owning a house & $(7) 23.3 \%$ & $(6) 20 \%$ & $(9) 30 \%$ \\
Marrying & $(12) 40 \%$ & $(5) 16.7 \%$ & --- \\
Studying abroad & $(4) 13.3 \%$ & --- & --- \\
Traveling & $(2) 6.7 \%$ & --- & --- \\
Taking care of the child & --- & $(17) 56.7 \%$ & $(15) 50 \%$ \\
Finishing High School & --- & $(12) 40 \%$ & $(16) 53.3 \%$ \\
There is no project & --- & $(1) 3.3 \%$ & $(4) 13.3 \%$ \\
Tidying up childcare & --- & --- & $(5) 16.7 \%$ \\
Leaving the institution & --- & --- & $(3) 10 \%$ \\
No wanting to have the child & --- & --- & $(1) 3.3 \%$ \\
Wanting to meet the father & --- & --- & $(1) 3.3 \%$ \\
\hline
\end{tabular}

In Group A, it can be observed that the majority ( $\mathrm{n}=22,73.3 \%$ ) of young girls have as their life project to go to college. The speech of one of the teenagers represents this desire.

Now I'm in the 2nd year, right. So next year, I'm going to work hard, go through college. I will study medicine; I will do obstetrics or pediatrics. I really want to be the doctor in the future that will make a difference in patients' lives. (GA E1, 17 years)

The projects of working and getting married by Group $A$ adolescents appear in the same proportion $(n=12,40 \%)$. Some lines of teenagers demonstrate these dreams among others.

$$
\begin{aligned}
& \text { I'm going to journalism school, I want to finish, get a good job } \\
& \text { preferably, get married, have a child and so will buy a house, buy } \\
& \text { a car, live well, not be rich, but live without being in need. (GA } \\
& \text { E13, } 18 \text { years) }
\end{aligned}
$$

Regarding the life projects of pregnant adolescents in Group $B$, the most reported plans were to look after their child $(n=17$, $56.7 \%)$, work $(n=17,56.7 \%)$, and go to college $(n=15,50 \%)$. Almost half ( $n=12,40 \%)$ of the girls in this group reported willingness to 
finish high school, but in Group A this did not appear, precisely because they were studying or had already finished high school. The following statement demonstrates these projects:

Ah, my project is now my son right! After finishing college, I want to work in my field and then graduate. (GB E5, 18 years)

The teenager's account below describes her projects based on trajectories that lead to their realization, she has the support of her partner to continue carrying out her plans even with the new family member on the way.

As I will win next January next year, in the middle of the year I want to go to college. My husband encourages me a lot, he will start studying civil engineering. (GB E12, 18 years)

The following teenager's statement clearly shows that pregnancy has interrupted her projects, but she wants to do them again soon.

I can't wait to go back to school. I hate being home doing nothing, especially now that I can't walk much that my feet already swell. I can't wait to go back to college, work. (GB E13, 18 years)

In Group C, the most reported projects by adolescents were: willingness to finish school (high school) $(n=16,53.3 \%)$, work $(n=16,53.3 \%)$, child care $(n=15,50 \%)$ and have their own home $(n=9,30 \%)$. The following statement demonstrates these projects:

Ah, for now I prefer to take care of my daughter. Then I want to work, I want to get married and have my house, right? (GC E24, 18 years)

Some of the adolescents' statements demonstrated their desire to work to provide better financial and affective living conditions for their children.

I want to be responsible, take good care of the child. I want to work, give everything I can, but not so good and the best. I want to give her a good life. Always give attention like this, affection, attention, something I never had and give, pass it to her. Being able to be with him [partner] to raise her [daughter]. (GC E9, 18 years)

Other adolescents demonstrated difficulties in having to assume motherhood, shifting the role of care to another, in this case the day care center.

Ah when this baby is born now, I'll find a way to take care of myself, fix my hair, get a service for myself, put her in the nursery. (GC E11, 18 years)

The day care center as a place of support and support in caring for the child was reported by other adolescents in this group, which did not happen in Group B. In this group, the adolescents reported that they would return to study and work, as family members and partners would help in caring for the child, pointing to the importance of the family and partner environment at this time.

I'll wait to be able to do my six months to be able to put in day care, to have a job, right? I want to have my home, finish my studies. (GC E12, 18 years)
Adolescents who reported having no life project were $13.3 \%$ $(n=4)$, in Group B only one said not to have a project and in Group A all reported some project.

Ido not have it yet. My head is a little confused. (GC E30, 16 years)

It was observed that the adolescents in Group C showed the least desire to go to college $(n=4,13.3 \%)$ compared to the other groups (Group A n=22, 73.3\% and Group B n=15, 50\%). However, 16 adolescents (53.3\%) from Group C reported willingness to finish high school compared to 12 teenagers from Group B (40\%). This should be related to the age-grade lag where Group $C$ had a higher lag compared to the other groups.

Group $C$ adolescents reported more desire to have their own home ( $n=9,30 \%)$ compared to the other groups (Group $A n=7$, $23.3 \%$ and Group $B n=6,20 \%$ ). This may be due to housing condition data, as this was the group with the lowest percentage of home ownership compared to the other groups. Another interesting fact is that Group $C$ was the only one that did not mention the desire to marry, in Group A, this project was the second most mentioned $(n=12,40 \%)$, in Group B it was also reported $(n=5$, $167 \%$ ), but to a lesser extent compared to Group A.

\section{DISCUSSION}

The data from the present study agree with the IBGE (Brazilian Institute of Geography and Statistics - Instituto Brasileiro de Geografia e Estatística) data ${ }^{(22)}$ that adolescent mothers have less time to study than adolescents without children, indicating the difficulty of combining maternity and school attendance. In addition, research has shown that the situation of domestic violence further aggravates adolescents' permanence in school, and many of them dropped out of school even before pregnancy, showing a little of the meaninglessness that this institution has in the lives of these adolescents. This data seems to point to the absence of educational policies for both children and adolescents victims of domestic violence and for pregnant adolescents.

UNICEF ${ }^{(23)}$ points to the main obstacles that hinder the universalization of access and permanence of children and young people in school which are: economic barriers (poverty and child labor); educational barriers (teaching of content away from the student's reality, lack of appreciation of the education professional, insufficient number of schools, lack of accessibility to students with disabilities, inadequate infrastructure and lack of public transportation); and sociocultural barriers (racial discrimination, exposure to violence and teenage pregnancy).

It is clear from the data that the group with the highest school dropout and the highest age-grade gap was in Group C, in which there was not only the pregnancy involved in its context, but also the domestic violence suffered at some point in their lives. Researchers have already demonstrated the relationship between domestic violence and poor school performance and/or dropout ${ }^{(14-16)}$. To the problem of domestic violence can be added structural violence, which is determined by socioeconomic inequalities, which involves issues such as the rule of law, income distribution, employment policies, housing, land reform, education, physical and mental health, and exposes people to social exclusion ${ }^{(23-24)}$. 
The data observed in this study indicated that all adolescents had access to water, electricity, sewage and garbage collection. Regarding housing and family income, a significant difference was observed between the three groups (housing - $p<0.004075$ and family income - $p<0.000369)$. However, when pairwise statistical analysis was performed, it was found that there was no significant difference between A-B (housing $\mathrm{p}<0.202595$, family income - $p<0.131286$ ), these data reinforce the above study of the relationship between structural violence and domestic violence $^{(23-24)}$. This information should reflect on the absence, negligence of the State and non-compliance with Article 227 of the Federal Constitution ${ }^{(25)}$ and Article 4 of the Brazilian Statute of Child and Adolescent (Estatuto da Criança e do Adolescente) ${ }^{(26)}$.

It is the duty of the family, society and the state to guarantee the right to life, health, food, education, leisure, professionalization, culture, dignity, to the child, adolescent and young person with absolute priority. respect, freedom and family and community life, besides protecting them from all forms of neglect, discrimination, exploitation, violence, cruelty and oppression ${ }^{(25-26)}$.

When the barriers of social exclusion are broken down and social, cultural and professional opportunities are offered to young people, they realize that they are taking advantage of them. Cortes Neto et al. ${ }^{(27)}$ demonstrated the benefits of sports social projects in the process of social inclusion and as a measure of protection of children and adolescents in situations of vulnerability and social risk. Bolzani and Bittar ${ }^{(28)}$ developed visual arts workshops aimed at empowering and developing personal skills in socially vulnerable adolescents and identified that project participants"showed greater interest in caring for themselves and their personal appearance, in addition to have changed their perception of each other" (p. 7). The authors $^{(28)}$ concluded that the holding of the workshops enabled improvement in social, emotional and cognitive skills, contributing to the confrontation of the reality in which young people are inserted.

Regarding life projects, the girls in Group A compared to the other groups reported the most about the desire to "go to college" and it was the only group that mentioned the desire to "study abroad" and "travel". Dreaming, wishing, making plans for the future are typical actions of the adolescent phase, a period to invest in vocational training and qualification, as well as a moment of personal maturity ${ }^{(29)}$.

Research conducted with pregnant and non-pregnant adolescents identified that the plans of the adolescents are similar, what changed was the postponement of some plans by pregnant women $^{(30)}$. In the present research this could also be observed, some young people from Group B who had family support reported about the desire to carry out their plans, but due to pregnancy had to postpone for a while.

It was also observed that in Group B and Group C, most adolescents want to take care of their children, work and study. These data agree with research conducted in Chicago ${ }^{(31)}$, which found that the most important factors for short-term pregnant adolescents were financial, residential and current life stability.

It can be seen that one of the differences between Group B and $C$ seems to be in the investment in relation to studies, in Group B most report wanting to "go to college" whereas in Group C a larger number say they want to "finish high school". This data reveals the age-grade gap and dropout rate of the Group C adolescents already pointed out, emphasizing the negative impact of domestic violence experienced by these young people not only on the history of school life, but also on the continuity of future investment in studies. This points to a possible lack of professional qualification of these young people, making it difficult to enter the labor market, causing low remuneration of work and allowing lower job opportunities and changes in socioeconomic and living conditions ${ }^{(32-34)}$. The data once again seems to point to a lack of educational and social policies that enable other life opportunities for young women.

Family and peer support in Group B could be observed in some speeches, as well as in the absence of reports of wanting to place the child in the nursery. The search for help and professional support in caring for the child could be observed in the words of some Group C adolescents who want to put their child in day care so that they can work, study and even take care of themselves. These data also point to the lack of support and support either from family or partner with the adolescents in Group C. This increases the difficulty of returning to school, as well as investment in professional qualification, as well as lack of support in caring for children. the baby. This situation of helplessness experienced by the young women of Group C contributes to their thinking about short-term projects or not even thinking about them. These data agree with the research by Costa and $\mathrm{Assis}^{(5)}$ about the interference of vulnerability situations in the projects of young people's lives.

A study ${ }^{(8)}$ conducted in Mexico showed the expectation of pregnant adolescents regarding education. When the expectation of the adolescent's mother was high, influencing the school stay and the continuity of studies after the baby's birth, the adolescent's expectation followed that of her mother. In cases where there was no such incentive, expectations were low, prevailing school dropout and non-continuity of studies after the baby's birth. The results of this study converge with the present research on the importance of family support to pregnant adolescents and the process of continuity of their life projects.

In Group C, the crossing of violence can also be observed in life projects such as "leaving the institution","'having no project","not wanting to have a child", "knowing the father". Several studies ${ }^{(5,8,10,13-16,32-33)}$ show how violence against children and adolescents harms the physical, mental and emotional health of individuals and that this may be one of the factors related to teenage pregnancy. In addition, it was observed how much adolescents who have experienced or experience situations of violence have their future expectations of limited lives. This agrees with the study by Bravo et $\mathrm{al}^{(8)}$ that demonstrates how much educational life projects are related to parental incentive and model.

The study by Updegraff et al ${ }^{(35)}$ also pointed to the importance of family support at the time of teenage pregnancy by observing the development of motherhood, care for oneself and the baby when they are supported. In addition to family, another study ${ }^{(36)}$ points to the importance of teachers and schools welcoming pregnant adolescents in order to avoid dropout and encourage further studies after the birth of the baby.

\section{Study limitations}

This study was conducted in just one moment with the adolescents, and it is interesting to carry out longitudinal research to follow up the life projects reported by the adolescents. 


\section{Contributions to nursing, health or public policy}

It is believed that the present work may contribute to the elaboration of public policies in the areas of health, education and social work for pregnant adolescents, especially for these young people who are in unfavorable social conditions and in situations of domestic violence.

\section{FINAL CONSIDERATIONS}

This study presented the analysis of social conditions and life projects of the three groups A, B and C. Regarding social conditions, it was observed that there was no difference between the three groups regarding age and race/color. The other aspects (marital status, education, living conditions and family income) showed a significant difference between the three groups with $p<0.05$. In the peer-to-peer analysis, there was no significant difference between $\mathrm{A}-\mathrm{B}$ in terms of housing condition and family income and between $\mathrm{B}-\mathrm{C}$ in marital status and education (studying). These data also culminated in the question of the absence of educational and social policies for pregnant adolescents and victims of domestic violence.

Regarding life projects, it was observed that adolescents in Groups B and C showed expectations for the future in the short term (taking care of their children and working). Group B adolescents, even in the face of pregnancy, were more willing to go to college than Group C, projecting their longer-term achievements in education among others. In group A all adolescents reported having projects for the future, demonstrating characteristic aspects of adolescence. The adolescents in Group C, on the other hand, mentioned that they had no projects, pointing to the interference of domestic violence in the girls' life planning. The support of family and partner was fundamental in the gestational process, as well as in the constitution of adolescents'life projects.

This study was limited to the analysis of the social conditions and life projects of the adolescents of the three groups. It was observed that themes such as mother-baby bond, transgenerational violence among others would be important to be studied and deepened, so that they can contribute to the strengthening of much needed services and policies in this area of adolescence, pregnancy and domestic violence.

\section{ACKNOWLEDGMENT}

Acknowledgment to the São Paulo State Research Support Foundation (FAPESP) for granting a postdoctoral fellowship that enabled this work to be done.

\section{REFERENCES}

1. Levisky DL. Adolescência e violência: a psicanálise na prática social. In: Levisky DL (org.). Adolescência pelos caminhos da violência. São Paulo: Casa do Psicólogo; 1998.

2. Macedo MMK, Azevedo BH, Castan JU. Adolescência e psicanálise. In: Macedo MMK (org.). Adolescência e psicanálise: intersecções possíveis (2 ${ }^{\mathrm{a}}$ ed.). Porto Alegre: EdiPUCRS; 2012.

3. Freud S. O mal-estar na civilização. In: S. Freud. Obras Completas, Volume 18 - O mal-estar na civilização e outros textos (1930-1936). São Paulo: Companhia das Letras; 2010.

4. Costa EFL, Oliveira CT, Dias ACG. Projetos futuros de estudantes do ensino médio de escola pública. Adolesc Saúde. [Internet] 2017 [cited 2019 Aug 21];14(4):31-40. Available from: http://www.adolescenciaesaude.com/detalhe_artigo.asp?id=681

5. Costa C, Assis S. Fatores protetivos a adolescentes em conflito com a lei no contexto socioeducativo. Psicol Soc. 2006;18(3):74-81. doi: 10.1590/S0102-71822006000300011

6. UNFPA. Estado de la Población Mundial. New York: UNFPA [Internet]. 2017. [cited 2018 Sep 27]. Available from: https://www.unfpa.org/sites/ default/files/sowp/downloads/UNFPA_PUB_2017_ES_SWOP_Estado_de_la_Poblacion_Mundial.pdf

7. Fundo das Nações Unidas para a Criança - Brasil. A cada 7 minutos, uma criança ou um adolescente morre vítima da violência [Internet]. 2017 [cited 2018 nov. 15]. Available from: https://www.unicef.org/brazil/pt/media_37371.html.

8. Bravo DY, Toomey RB, Umaña-Taylor AJ, Updegraff KA, Jahromi LB. Growth trajectories of Mexican-origin adolescent mothers educational expectations. Int J Behav Develop. 2017;41(2):165-74. doi: 10.1177/0165025415616199

9. Novellino MSF. Um estudo sobre as mães adolescentes brasileiras. Physis Rev Saúde Colet. 2011; 21(1): 299-318. doi: 10.1590/ S0103-73312011000100018.

10. Taborda JA, Silva FC, Ulbricht L, Neves EB. Consequências da gravidez na adolescência para as meninas considerando-se as diferenças socioeconômicas entre elas. Cad Saúde Colet. 2014; 22(1):16-24. doi: 10.1590/1414-462X201400010004

11. Pires R, Pereira J, Pedrosa AA, Vilar D, Vicente L, Canavarro MC. Contributo de fatores individuais, sociais e ambientais para decisão de prosseguir uma gravidez não planeada na adolescência: estudo caracterizador da realidade portuguesa. An. Psicol. 2015;33(1):19-38. doi: 10.14417/ap.827

12. Sabroza AR, Leal MC, Souza Jr PR, Gama SGN. Algumas repercussões emocionais negativas da gravidez precoce em adolescentes do município do Rio de Janeiro (1999-2001). Cad Saúde Pública. 2004; 20(sup.1): s130-s137. doi: 10.1590/\$0102-311X2004000700014

13. Dávila RF, Fajardo GDE, Jiménez CCA, Florido PC, Vergara CKC. Factores de riesgo psicosocial para embarazo temprano y deserción escolar en mujeres adolescentes. Rev Cienc Salud. 2016;14(1):93-101. doi: 10.12804/revsalud14.01.2016.11

14. Garwood SK, Gerassi L, Jonson-Reid M, Plax K, Drake B. More than poverty: the effect of child abuse and neglect on teen pregnancy risk. J Adolesc Health. 2015;57(2):164-8. doi: 10.1016/j.jadohealth.2015.05.004. 
15. Negriff S, Schneiderman JU, Trickett PK. Child Maltreatment and Sexual Risk Behavior: Maltreatment Types and Gender Differences. J Dev Behav Pediatr. 2015;36(9):708-16. doi: 10.1016/j.jadohealth.2015.05.004

16. Miura PO, Passarini GMR, Ferreira LS, Tardivo LSLPC, Barrientos DMS, Paixão RAP. Vulnerabilidade cumulativa: estudo de um caso de violência doméstica, toxicodependência e gravidez na adolescência. Rev Esc Enferm USP. 2014;48(esp.2):55-61. doi: 10.1590/ S0080-623420140000800009

17. Minayo MCS, Sanches O. Quantitativo-Qualitativo: oposição ou complementaridade? Cad Saúde Pública[Internet]. 1993 [cited 2019 Sep 20];9(3):239-62. Available from: http://www.scielo.br/pdf/\%0D/csp/v9n3/02.pdf

18. Hochman B, Nahas FX, Oliveira FRSde, Ferreira LM. Desenhos de pesquisa. Acta Cir Bras. 2005;20(Suppl-2):2-9. doi: 10.1590/ S0102-86502005000800002

19. Tardivo LSLPC, Pinto Jr AA. Inventário de frases no diagnóstico de violência doméstica contra crianças e adolescentes. São Paulo: Vetor; 2010. (Coleção IFVD; vol. 1).

20. Bardin L. A análise de conteúdo. 3a ed. Lisboa: Edições 70; 2013.

21. Palácio do Planalto (BR). Decreto n 8.381 de 29 de dezembro de 2014. Dispõe sobre o valor do salário mínimo [Internet]. 2014[cited 2015 Jul 7]. Available from: http://www.planalto.gov.br/ccivil_03/_Ato2011-2014/2014/Decreto/D8381.htm

22. Instituto Brasileiro de Geografia e Estatística-IBGE. Síntese de Indicadores Sociais: uma análise das condições de vida da população brasileira 2014[Internet]. Rio de Janeiro: IBGE. 2014[cited 2015 jul. 7]. Available from: http://biblioteca.ibge.gov.br/visualizacao/livros/liv91983.pdf

23. United Nations Children's Fund. A familiar face: violence in the lives of children and adolescents. UN: New York; 2017.

24. Organización Mundial de la Salud. Maltrato infantil [Internet]. 2016 [cited 2018 Nov. 15]. Available from: http://www.who.int/mediacentre/ factsheets/fs150/es/.

25. Congresso Federal (BR). Constituição 1988. Constituição da República Federativa do Brasil. Brasília (DF): Senado; 1988.

26. Presidência da República (BR). Lei n 8.069, de 13 de julho de 1990. Dispõe sobre o Estatuto da Criança e do Adolescente.

27. Cortes Neto ED, Dantas MMC, Maia EMC. Benefícios dos projetos sociais esportivos em crianças e adolescentes. Saúde e Transformação Social [Internet]. 2015 [cited 2019 Aug 21]; 6(3): 109-17. Available from: http://incubadora.periodicos.ufsc.br/index.php/ saudeetransformacao/article/view/3561/4489

28. Bolzani B, Bittar CML. Oficinas de artes visuais para adolescentes em situação de risco social: uma possibilidade para ações em promoção de saúde. Adolesc Saúde[Internet]. 2017 [cited 2019 Aug 21];14(1):7-13. Available from: http://www.adolescenciaesaude.com/detalhe_artigo. asp?id $=630$

29. Winnicott DW. A família e o desenvolvimento do indivíduo. São Paulo: Martins Fontes; 2005.

30. Dias ACG, Oliveira CT, Jager ME, Patias ND. Semelhanças e diferenças nos planos para o futuro de adolescentes gestantes e não gestantes. Adolesc Saúde[Internet]. 2013 [cited 2019 Aug 21];10(3): 7-13. Available from: http://adolescenciaesaude.com/detalhe_artigo.asp?id=375

31. Universidade de Chicago. Family planning: contraceptive research. Future Goals of Adolescent Mothers [Internet] 2011 [cited 2018 Nov 12]. Available from: http://familyplanning.uchicago.edu/research/studies-by-topic/postpartum-abcs/Goals.pdf

32. Kudlowiez S, Kafrouni R. Gravidez na Adolescência e Construção de um Projeto de Vida. Psico, Porto Alegre, PUCRS [Internet] 2014 [cited 2018 Nov 12];45(2):228-38. Available from: https://dialnet.unirioja.es/descarga/articulo/5633337.pdf

33. Lomonaco BP, Nakasu MVP, Silva TSS, Hercowitz V, Santos VS. Mundo Jovem: desafios e possibilidades de trabalho com adolescentes. São Paulo: Fundação Tide Setubal; 2008.

34. Lima NRB, Nascimento EGC, Alchieri JC. História de vida da mulher: qual a verdadeira repercussão da gravidez na adolescência?. Adolesc Saúde [Internet]. 2015 [cited 2018 Nov 12];12(1):57-65. Available from: http://adolescenciaesaude.com/detalhe_artigo.asp?id=476

35. Updegraff KA, Umaña-Taylor AJ, McHale SM, Wheeler LA, Perez-Brena NJ. Mexican-origin youth's cultural orientations and adjustment: changes from early to late adolescence. Child Develop. 2012;83:1655-71. doi: 10.1111/j.1467-8624.2012.01800.x

36. Erdmans MP. Title IX and the School Experiences of Pregnant and Mothering Students. Hum Soc. 2012;36(1):50-75. doi: 10.1177/0160597611433269 